\title{
Exploration on Financing Path of Innovative Listed Companies
}

\author{
Li Jin \\ Management School, University of Jinan, Ji'nan, 250002, China
}

Keywords: Innovative listed companies, Financing way, Equity financing, Debt financing

\begin{abstract}
For innovative listed companies, financing is one of the important issues influencing enterprise development. This paper introduces financing ways of innovative listed companies, compares debt financing and equity financing from the perspective of qualitativeness and cost, analyzes their advantages and disadvantages and puts forward a method for optimizing enterprise financing structure. For innovative enterprises, scientific and reasonable solution of their financing problems is an important strategy for guaranteeing their healthy development.
\end{abstract}

\section{Introduction}

The development of innovative enterprises has an important function for improving the overall innovation level of China and promoting the development of Chinese economic society. Financing is very important for innovative enterprises as they need a lot of funds for satisfying their production and management after appearing on the market. The selection of financing way of innovative enterprises becomes an important research topic. For innovative listed companies, choosing an appropriate financing way is the important premise of guaranteeing their healthy development. This paper describes the importance and risk defense of financing so as to achieve the financing objective of minimum cost and best effect.

\section{Financing demands of innovative enterprises in different periods}

Risk is the main feature of innovative enterprises. That is to say, risk accompanies the operation of innovative enterprises in their growth process. Innovative enterprises in different periods have different risks, fund demands and financing ways. Table 1 shows fund demands of innovative enterprises in different periods.

Table 1. Fund demands of innovative enterprises in different periods

\begin{tabular}{ccccc}
\hline Life cycle & Risk & $\begin{array}{c}\text { Success } \\
\text { rate }\end{array}$ & $\begin{array}{c}\text { Fund } \\
\text { demand }\end{array}$ & Financial support mode \\
\hline Seed stage & $\begin{array}{c}\text { Extremely high } \\
\text { technical risk }\end{array}$ & $<10 \%$ & Small & $\begin{array}{c}\text { Angel investor, special } \\
\text { appropriation }\end{array}$ \\
\hline $\begin{array}{c}\text { Start-up } \\
\text { stage }\end{array}$ & $\begin{array}{c}\text { High operational } \\
\text { risk }\end{array}$ & $<50 \%$ & Large & $\begin{array}{c}\text { Venture investor, policy bank } \\
\text { loan, government grant }\end{array}$ \\
\hline $\begin{array}{c}\text { Growth } \\
\text { stage }\end{array}$ & $\begin{array}{c}\text { Medium } \\
\text { operational risk }\end{array}$ & $\begin{array}{c}\text { About } \\
70 \%\end{array}$ & Large & $\begin{array}{c}\text { Second board market, policy } \\
\text { bank, commercial bank and } \\
\text { private financial lending }\end{array}$ \\
\hline $\begin{array}{c}\text { Maturation } \\
\text { stage }\end{array}$ & Low & $\begin{array}{c}\text { About } \\
90 \%\end{array}$ & Large & $\begin{array}{c}\text { Commercial ban load, main } \\
\text { board market }\end{array}$ \\
\hline
\end{tabular}

\section{Financing ways of innovative listed companies}

Financing of innovative listed companies includes external financing and internal financing based on capital source. In developed countries, there are two different types of financing ways of enterprises. Developed countries represented by America and England mainly use direct financing way, while those represented by Germany and Japan mainly use indirect financing way. Table 2 shows the financing structure of listed companies in seven major developed countries. 
Table 2. Financing structure of listed companies in seven developed countries

\begin{tabular}{|c|c|c|c|c|c|c|c|c|}
\hline $\begin{array}{c}\text { Financing } \\
\text { structure (\%) }\end{array}$ & $\begin{array}{c}\text { Ameri } \\
\text { ca }\end{array}$ & Canada & France & $\begin{array}{c}\text { Germa } \\
\text { ny }\end{array}$ & Italy & $\begin{array}{c}\text { Englan } \\
\text { d }\end{array}$ & Japan & $\begin{array}{l}\text { Avera } \\
\text { ge }\end{array}$ \\
\hline $\begin{array}{c}\text { Internal } \\
\text { financing }\end{array}$ & 75 & 54 & 46 & 62 & 44 & 75 & 34 & 55.71 \\
\hline $\begin{array}{l}\text { External } \\
\text { financing }\end{array}$ & 25 & 46 & 54 & 38 & 56 & 25 & 66 & 44.29 \\
\hline $\begin{array}{c}\text { Equity } \\
\text { financing }\end{array}$ & 13 & 19 & 13 & 3 & 13 & 8 & 7 & 10.86 \\
\hline Debt financing & 12 & 27 & 41 & 35 & 43 & 17 & 59 & 32.00 \\
\hline Others & 0 & 6 & -5 & 12 & 4 & -7 & 0 & 1.43 \\
\hline
\end{tabular}

Famous pecking order theory considers that enterprises should choose internal financing first. When it is necessary to use external financing, it's better to choose debt financing prior to equity financing. Table 2 shows the financing structure of listed companies in seven developed countries. Data shown are consistent with pecking order theory.

In China, state-owned innovative listed companies have experienced the transformation from indirect financing to direct financing. Let's take Sinopec for example. In terms of financing way, Sinopec has achieved the optimization of debt structure and reduction of cash outflow for enterprises by means of special financing.

\section{Comparison of equity financing and debt financing}

\section{Qualitative comparison}

Equity financing is characterized by universality, permanency and irreversibility. Universality is mainly manifested in the utilization of funds. Funds obtained by equity financing can be used for both enterprise operation and investment activities. The use of funds obtained by debt financing is restricted by creditor and policy. In terms of universality, equity financing has obvious advantages. For permanency, equity financing does not need planning and has no expiration. Only when enterprises need liquidation should they be repaid. Therefore, equity financing has very important function for guaranteeing the minimum standard of fund demand of enterprises. After equity financing, enterprises do not need to pay fixed interest. Dividend payment and payment amount depend on business operation. This avoids financial crisis of enterprises caused by the failure of repayment upon expiration. Compared to debt financing, equity financing can achieve a larger scale without the limitation of net asset of enterprises. It is an important feature of equity financing.

Besides advantages described above, equity financing has another vital feature, i.e. it can improve the proportion of long-term debts in the capital structure of enterprises. This has very positive function for improving the stability of debt structure. As equity financing reflects the increase of equities in the balance sheet, this can effectively reduce the asset-liability ratio and debt asset ratio of enterprises with high asset-liability ratio and is conducive to the optimization of capital structure. In addition, equity financing can increase equity cost of enterprises and provide guarantee for creditors to avoid great loss. It is very conducive to improving the credit rating of enterprises and reducing their debt financing costs. Meanwhile, it can provide favorable support for the use of more debt capitals.

Equity financing has certain deficiencies. Compared to debt financing, the expected yield is required to be higher than that of debt financing as equity investors in equity financing undertake higher market risks than debt financing. Therefore, equity financing has higher costs. Compared to equity financing, costs of debt financing can be deducted before tax. When positive influence in financial framework is greater than the negative influence of financial costs, it has strong financial leverage function. However, equity financing does not have such function. Moreover, when a company conducts equity financing by means of additional issue, the participation of new investors will reduce the shareholding ratio of existing shareholders and produce certain influence on the control power of existing shareholders in the company. 


\section{Cost comparison}

Debt financing means that enterprises raise funds by selling bond and bill. In this financing way, creditors have the right to recover principal and interests upon expiration. From the perspective of cost, loan interests of financial institutions or expected yield of bond are used as financing costs in this financing way.

Equity financing means that enterprises issue shares or securities with rights and interests. Costs of equity financing are the rate of return of cash dividends. Generally, equity securities investors use capital asset analysis model to combine stock risk and expected yield when analyzing the investment. In capital asset pricing model, equity costs is equal to the product of risk premium of risk-free interest rate and risk factor.

According to the comparison of costs of debt financing and equity financing, both financing ways have advantages and disadvantages due to differences in risk and cost. For example, debt financing will increase the financial risk of enterprises and damage the interest of administrators. Equity financing will dilute and damage shareholder benefit. In essence, the selection of financing way is a contest for opinions and interests of enterprise managers and shareholders. Its final result is determined by the final result of contest for interests of enterprise managers and shareholders.

\section{How to optimize the financing structure of innovative listed companies}

Financing problem will be inevitably involved in the rapid development process of enterprises. To satisfy demands of enterprises, it is required to conduct positive analysis and establish a financing structure combining bank load, public stock issue and bond issue for financing activities of enterprises with the help of relevant financial and monetary policies based on the domestic and foreign financing environment and actual situation of enterprise development. To achieve these contents, the following can be implemented.

\section{Use debt financing instruments}

The full name of debt financing instruments is debt financing instruments of non-financial enterprises in interbank bond market. Debt financing instruments refer to negotiable securities issued by non-financial institutions with legal personality in interbank bond market which require capital repayment with interest within certain time limit. Currently, debt financing instruments mainly include short-term financing bill, medium term note, collection notes of small and medium-sized enterprises and super short-term financing bill.

Debt financing instruments can help enterprise management in capital liquidity and have the following characteristics: first, issuing objects of debt financing instruments are institutional investors in interbank bond market, including bank, security company, fund company and insurance asset management company. Second, participants of issuance of debt financing instruments include lead underwriter, rating agency, credit addition institution, auditing firm and law office, which mainly conduct financial audit and rating for issuing enterprises. Lead underwriter is responsible for preparing raising instruction and arranging enterprises for information disclosure. Third, debt financing instruments use market-pricing method. Issuing interest is determined according to the level of enterprises and financing instruments in combination with the funds face of banking market. Generally, the pricing is lower than benchmark interest rate of bank loan. Moreover, it can be adjusted flexibly according to fund demand in the issuing process. Forth, issuing in marketing way. Debt financing instruments are registered and issued according to relevant work instructions of National Association of Securities Dealers. After registration for once, issuing can be analyzed according to fund demand and market conditions and the examination and approval of regulator are not required.

\section{Use the financing platform of domestic and foreign innovative listed companies to improve the capital structure of enterprises and reduce financial risk in equity financing way}

A share issuance is the main form of financing in which Chinese innovative listed companies offer stock rights for sale. A share means issuing additional stocks to domestic and qualified overseas 
institutional investors in A share market. $\mathrm{H}$ share additional issuance means issuing additional stocks to overseas investors in Hong Kong market. $\mathrm{A}+\mathrm{H}$ allotment means issuing rights to all shareholders in A share and Hong Kong markets.

Relevant Chinese laws and regulations stipulate that the quantity of A share public offering stocks shall not exceed $1 / 5$ of the number of issued shares. There are certain limitations on its issuing scale. A share public offering will make both new and old shareholders enjoy profit and growth, i.e. produce allocating effect on existing shareholders. Relative to the issuing scale of $\mathrm{A}$ share, $\mathrm{A}+\mathrm{H}$ shares can have a larger issuing scale. However, according to share allotment principle of $\mathrm{A}$ and $\mathrm{H}$ same-stock same-right, cash subscription of major shareholders is required. This imposes great pressure on funds of major shareholders. The price difference between different capital market shares and $\mathrm{H}$ share makes stock allotment pricing method complicated.

\section{Discuss off-balance-sheet financing ways and strive to further optimize assets and liabilities and financial indicators}

Asset securitization is an innovative financing way in direct financing in the capital market. Asst securitization and other financial products issued are similar. Issuers achieve financing by issuing assets backed security to investors. The repaying source of asset securitization products is a series of future recyclable cash flow. Assets producing such cash flow support asset securitization products in the form of basic mortgage asset. Therefore, the essence of financing way of asset securitization is the sales of future recyclable cash flow for achieving the purpose of corporate finance.

Financing based on the credit of special assets is the essential feature of asset securitization. That is to say, the independence of basic mortgage asset credit is the essential feature of asset securitization. This is the greatest difference of asset securitization and bank financing and stock and bond financing with the overall credit of enterprises as basis. In terms of independence of such credit, enterprises do not care about their overall credit during financing with asset securitization; instead, they care about credit enhancement provided for securitization financing according to special assets during financing.

The independence of basic mortgage asset credit can be realized through bankruptcy isolation and real sale. That is to say, it is required to first achieve the effect of bankruptcy isolation in institutional arrangement of special-purpose entity and then achieve the result of real sale in the specific transfer process of basic mortgage asset. From the perspective of state-owned innovative listed companies, real sale represents actual transfer or sale of national asset. Therefore, the approval of SASAC is required. According to the actual situation of China, asset securitization financing way has certain deficiencies in tax administration, accounting system, credit rating, laws and regulations and supervision. Therefore, only by establishing a set of accounting systems specific to asset securitization business with clear provisions on rights, obligations and legal status of market subject and relevant valuation model can state-owned innovative listed companies actually use asset securitization way to achieve the purpose of enterprise financing.

\section{Conclusion}

Innovative enterprises refer to those having core technologies and famous brand with proprietary intellectual property rights, good innovation management and culture, overall technical level holding an advanced position in the same industry and advantages and sustainable development ability in market competition. Innovative listed companies will meet financing problems in the development process. Therefore, it is necessary to handle domestic and foreign pressure of competition positively under the premise of mastering their actual situation, and meanwhile seize the rare opportunity of existing rapid development of capital market, analyze risks, earnings and costs of various financing ways, realize financing demands of enterprises with the optimal financing structure and strive to realize minimum costs and maximum market value during financing. 


\section{References}

[1] You Yong, Pang Sidi, Zhang He. Research on Relations of Financing Way, Governance Structure and Technical Innovation Ability of High-tech Enterprises. Modern Economic Science, 2010,32(3)

[2] Li Yi, Li Ke. Analysis on Financing Obstacles of Chinese Innovative Enterprises. Modern Business Trade Industry, 2011,23(1)

[3] Sun Minggao. Development and Financing Strategies of Innovative Enterprises. South Journal, 2010,(4)

[4] Li Shi. Innovation and Development - Focus on Construction of Investment and Financing System in Zhongguancun Science Park. International Financing, 2007, 85(11)

[5] You Yong, Chang Qinghua. Relations of Innovation Type, Financing Way and Market Strategies - Empirical Study Based on Chinese High-tech Enterprises. Studies in Science of Science, 2008, 26(4) 